Historic, archived document

Do not assume content reflects current scientific knowledge, policies, or practices. 
,

- 


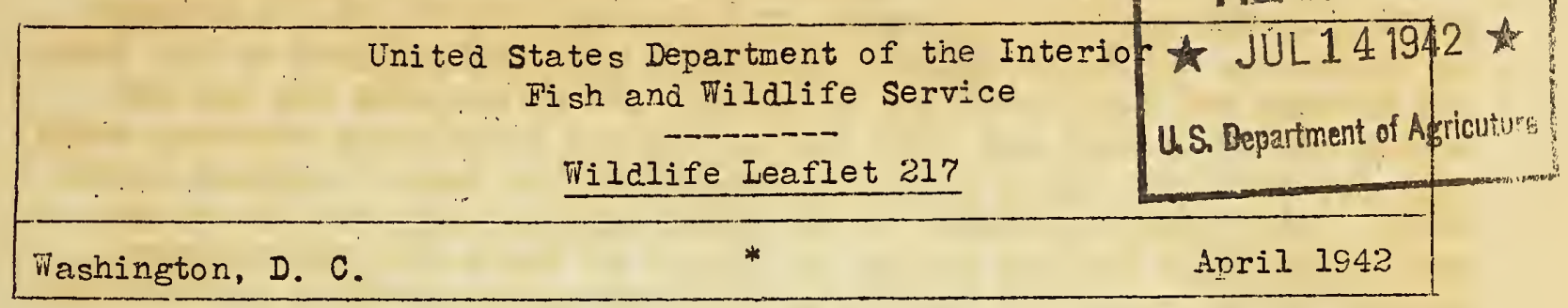

\section{WAR AND WIDDLIFE}

By W. E. Crouch

Chief, Division of Game Management

There has been much speculation regarding the effects that World Far II will have on wilalife. Wildlife administrators, conservation organizations, members of Congress, and others have made inquiries as to the prospects and also concerning the possible effect of the war on funds available for the protection and restoration of vildilfe. In order to give somewhat intelligent answers to these questions, a study was made of the effects of World Nar I. Data on various factors over a contimous period of years, beginning before the last war and ending after the war, were collected from State game departments and other sources. These made possible an enlightening analvsis of the situation. during the last war. It was not possible to obtain accurate information from all of the states as several did not have game departments in the year 1916, some of the departments were young at that time with incomplete records, while others of the state agencies could not locate records covering the last war period. It was possible, however, to get sufficient data from which to make a definite analysis of the subject. Many persons have predicted that one effect of the present war would be to decrease materially the funds available for wildife management. Contrary to this belief, the data compiled from 2a states from which accurate figures were obtained showed that there was on the whole a gradual increase in funds available to the States fo: wildife conservation through the previous war period, and a much larger increase immediately following the war. Stating this in definite figures, there was an increase in funds of 5 percent from 1916 to 1917, 8 percent from 1917 to 1918 , and 20 percent from 1918 to 1919. Only three states out of the 22 indicated any appreciable decrease in funds for wilclife purooses, while the others reported either a neэrly constant amount of funds or an increase in funds during the war period.

It has been of ten stated also that the present war mould cause a decrease in the number of hunters and sport fishermen. Yet the data covering the last Torld Nar showed that there was a gradual increase in the number of hunters and sport fishermen during the var and a pronounced increase immediately following. The increases vere 1.6 percent from 1916 to 1917, 2.6 percent from 1917 to 1918 , anc nearly 30 percent immediately after the war from 1918 to 1919. Only four states reported

a slight decrease. 
While it is true that a considerable portion of our population is serving in the armed forces, many of these individuals are not hunters or fishermen. Of those. who are sportsmen, many are replaced on the fishing streams and hunting fields by workers on war projects who can now better afford to hunt and fish, and by novices in military training camps who, for the first time, have been exposed to the lure of outdoor recreation. Also, many sportsmen in the armed services will be able to do some hunting and fishing during the period of their military training. Another factor that will tend to keep up the number of those who will go hunting and fishing is the normal increase in population which brings forward each year a considerabie number of persons who have reached the age for active participation in these sports. Available data show that years of financial depression brought more reducing effects on the finances of the various State game departments and on the number of persons engaged in hunting and fishing than did the war years. The information at hand and a study of the present situation indicate that during the year 1942, the first year of the present war for the United States, the number of persons who will seek recreetion in hunting and fishing will not be materially les than in 194.I. There probably will be fewer man days of hunting and fishing because many will be too busy helping to win the war to spend much time with runting guns and fishing tacikle. Furthermore, increased incone taxes will lessen the number of days that many are able to devote to favorite sports. Inability to purchase automobiles and tires also will decrease the number of days the hunters and fishermen can engage in field recreation; and, no doubt, will $t \in n d$ to decrease the number of persons who will hunt and fish, but in a much less degree. There will be more pooling of automobile transportation and use of other means of travel. Certain classes of persons who generally depend on hunting and fishing for their recreation will be able to obtain automobile tires, and they will, no doubt, share transportation with some of the less fortunate sportsmen.

Although it is true that the war will reduce materially or even stop the manufacture of sporting arms and ammunition, the, best information obtainable indicates that there are sufficient stocks of ammuition and arms in the hands of sportsmen and aealers to take care of hunting needs at least for this year and probably for another year or longer. It should be noted, also, that except for a very limited number of items, sporting arms and ammuition have no value as "equipment for organized military forces.

Many war-time factors, some of which have been mentioned, are now coming into effect and will have influences on the wildlife of this country. Those engaged in wildlife management are being requested by certain groups to stop all huting and sport fishing during the war. Many arguments are used, among which are the necessity of saving for war purposes, ammunition and materials that go into its manufacture; saving of gasoline and automobile tires; and the preserving of game for men in the military services when they return. Also, the argument is presented that now is the opportune time to give wildlife a chance to increase abundantly and thus insure its conservation. It must be remembered, however, that what 
is good game management in times of peace is al so good game management in times of war. Wildlife plays an important part in peace-time recreation, and shovld play an. important part in war-tine recreation. Under war conditions recreation is extremely important in keeping up the national morale. Furthermore, good geme management includes the wise harvesting of a game crop which is renewable from year, to year, provided sufficient breeding stock is retained. In addition to furnishing recreation, the proper harvesting of the game crop can and does supply valuable food. There are more than 900,000 big game aninals, including deer, elk, moose, and antelope killed in the United States each year, which at an average of only 90 pounds each, dressed, represent about $81,000,000$ pounds of meat. It is estimated that during the last year i5,000,000 waterfowl, 20,000,000 rabbits, 15,000,000 upland game birds, and more than 4,000,000 other small game rere kilied, which, averaging only one pound each dressed, would supply an additional 54,000,000 pounds of food. This makes a total of $135,000,000$ pounas of meat in game animals and birds, to which can be added the game fishes taken to replace neat needed in our war effort. There are more than 12,000,000 sport fishermen in the United states, and it is conservatively estimated that each of the se will catch on the average more than 25 pounds of fish per year. In fact, information available shows that the average catch is above 30 pounds in many States; in California it is inown to exceed 50 pouncis. However, on the basis of an average of only 25 pounds of sport fish anvully for each fisherman, there is supplied in this country each year 300,000,000 pounds of game fish. Altogether this adds up to $435,000,000$ pounds of food available from the annual harvest of gane animals, game birds, and game fishes. According to the Quartermaster Corps of the United States Amy, the meat allowance per soldier each day is 18 ounces, but the full quantity is not always supplied. Using this generous ration of meat as a linit, the 435,000,000 pounds of wild game and gane ifsh used in American homes would replace enough beef, pork, poultry, commercial fish, and other meat to furnish each year sufficient of this food to an army of $5,000,000$ men for more than 77 days. It is important to note a.l so tha.t with proper management, this valuable contribution to our war effort can be made annually without dariage to the resource.

The Fish and Wildlife Service does not advocate letting down the bars so as to permit more killing of game to make a supply of meat immediately available. We should protect the breeding stock and harvest only the surplus that becomes available from year to year. Despite this reasonable principle, officials entrusted witn the welfare of the nation's wildlife are urged by certain groups as a, war measure to permit a raid on our game so a.s to furnish an unusual and immetiate supply of food and to economize on the expenditures necessary to protect and maintain our wildlife resources. To the uninformed some of these proposals may be: very plausible; and to the game hog and the man who wants to profit financially on our: game, the argument that discard many of the came laws, discharge the game wardens, and stop the salaries of game technicians and administrators is like a message from heaven. During the first vorld var a very few States accepted such argunents, liberalized their Iaws, and cut down enforcement activities in connection with certain wildife species. In so doing, a dependable source of food was immediately and 
greatly decreased, which, in some instances, has not yet been restored. Fortunately, this occurred in only a very few instances, and ir most States game resources were adequately maintained through the war period.

As in most wars, a food shortage existed during the last fiorld Har. It resulted in a strong demand for liberalization of game lams so that wildlife could be immediate y utilized in large quantities. Evidence is not lacking to indicate that the novements mere encouraged by persons desiring to profit by the commercial sale of zame and also by those wishing to carry on unlimited hunting and fishing. The matter was presented to the United States Food Acministration, and after carefulinvestigation and study the administration came to the conclusion that since wilalife conservation laws had been needed in peace and had operated to maintain from year to year a more abundant food supply, it was even more imortant that the restrictions should be continued and adequately enforced in war time so as to provide a continuing source of food.

Furs are important to the war effort as they are used to provide parts of clothing for soldiers who heve to fight in the colder climates and for the clothing of aviators. During the first World War, civilian and military demands for furs brought about a decrease in a few species of fur-bearing animals in severel locelities, and a few states permitted the taking of larger numbers of fur animals which reduced the breeding stock in sone instances to such an extent that the animals have made little recovery. The raw fur business in this country represents an industry valued at about $\$ 60,000,000$ annually. Although i urs shoula be utilized, their use shouId be reasonable and not so extensive as to prevent maximum ánnual production.

During World Far I, wilalife suffered in the vicinity of military training camps, and there is evidence that the same thing is occurring now. This indicates that we may expect a very noticeable increase in hunters when the war is over, as many young men for the first time are learning the use of firearms and the recreational possibilities of hunting. As stated previously, the muber of hunters and sport fishermen increased nearly 30 percent immediately following the last world par. The probability of a similar increase after the present war is a sood reason for conserving our gane wisely and in suficient numbers so that men who risked their lives in the war may be able to enjoy hunting and fishing when they come back.

It is difficult to determine accurately what will hapoen to wildlife as a result of the present war by drawing conclusions from the effects of the last one. From all sides we hear that this war is different, and, indeed, it is different in several respects. It covers nore territory and influences directly the activities of more of our people. Nore materials and food are needed. Personal transportation is restricted. We will have a larger army and a larger nav than in 1917 and 1918. Also, our nation's population is larger. Nevertheless, history tends to repeat'itself, and it is probable that we can profit much in wildife administration by using the experience gained in the last var. 